\title{
Analysis on the Effect of Groundwater Overexploitation Control in Water receiving region of the First Phase of the South-North Water Transfer Project
}

\author{
GAO Yuanyuan, LI Jia, HAO Qichen, YU Chu, MENG Suhua
}

${ }^{1}$ Bureau of South to North Water Transfer of Planning, Designing and Management, Ministry of Water Resources, Beijing 100038, China; ${ }^{2}$ Department of Sedimentation, China Institute of Water Resources and Hydropower Research, Beijing 100048, China

\begin{abstract}
The South-North Water Transfer Project is playing a more and more important role in ensuring economic and social development and maintaining a good ecological environment for north of China. However, long-term over-exploitation of groundwater has caused a series of ecological and environmental problems. The first phase of the South-to-North Water Transfer Project was successfully passed through in 2013 and 2014. The water supplied by this huge project provided critical water source for implementing groundwater overexploitation control. In order to promote the management and protection of groundwater resources, the overdraft areas had adopted comprehensive measures to reduce groundwater extraction, such as accelerating the construction of supporting projects, shutting down groundwater mining wells, improving the groundwater monitoring station network, and reforming the water resources fees and so on. The urban groundwater overexploitation control work has received good progress. Based on the investigation and statistics of groundwater overexploitation control in the water receiving region of the first phase of the SouthNorth Water Transfer Project, it was found that since the first phase of the South-to-North Water Transfer Project passing though, the water groundwater withdrawal decreased by $15.23 \times 10^{8} \mathrm{~m}^{3}$ by making full use of the water from the South-North Water Transfer Project, including $2.36 \times 10^{8} \mathrm{~m}^{3}$ in Beijing, $0.67 \times 10^{8} \mathrm{~m}^{3}$ in Tianjin, $6.39 \times 10^{8} \mathrm{~m}^{3}$ in Hebei, $3.84 \times 10^{8} \mathrm{~m}^{3}$ in Henan, $1.62 \times 10^{8} \mathrm{~m}^{3}$ in Shandong, and $0.35 \times 10^{8} \mathrm{~m}^{3}$ in Jiangsu, respectively. The number of groundwater withdrawal wells closed was 15202, including 331 wells in Beijing, 582 in Tianjin, 4895 in Hebei, 6213 in Henan, 2012 in Shandong, and 1169 eyes in Jiangsu, respectively. In terms of groundwater level, the trend of continuous decline in groundwater level has been effectively curbed in most areas of the water receiving region, however, in some areas the groundwater level is still declining due to the too large cumulative over-exploitation of groundwater. Shijiazhuang City was selected as typical monitoring site to explain the groundwater overexploitation control effect on groundwater level. The analysis of the monitoring data of typical monitoring sites showed that groundwater overexploitation control has a great influence on the groundwater level change in Shijiazhuang urban area. This study also puts forward some problems and suggestions in promoting the groundwater overexploitation control in the water receiving region, and provides reference for the construction of ecological civilization and national water security.
\end{abstract}

\section{Background of groundwater overexploitation control in the water receiving region of the South-to-North Water Transfer Project}

(1) A series of ecological and environmental problems caused by overexploitation of groundwater in the water receiving region

In the past 40 years, due to long-term and large-scale overexploitation of groundwater, the ecological environment of the water receiving region has been seriously damaged, and a series of major ecological problems has been re caused, including the continuous decline of regional groundwater level, the partial aquifer being drained or depleted, land subsidence, deterioration of water quality and sea or salty water intrusion. These problems have seriously restricted the sustainable development of economy and society and endanger national food security, ecological security and water supply security. Taking Hebei Province as an example, the ecological function of surface water in Hebei Province is basically lost, the ecological environment of groundwater is deteriorating, and the maximum settlement of Ganzhou City with the most serious land subsidence has exceeded $2.5 \mathrm{~m}$. The water level in Baiyangdian-the largest wetland protection area in North China, has been lower than the 
minimum water level to maintain ecological balance ${ }^{[1-2]}$. With the country's emphasis on the ecological environment and ecological civilization and the need for the integration of Beijing-Tianjin-Hebei construction, it is extremely urgent to solve the problem caused by overexploitation of groundwater in the water receiving region.

\section{Over-exploitation groundwater volume}

The first phase of the South-North Water Transfer Project involves six provinces, including Beijing, Tianjin, Hebei, Henan, Shandong and Jiangsu of Haihe River Basin, Huaihe River Basin and the Yellow River Basin. The area is densely populated and economically developed with prominent water supply and demand. Surface water and groundwater have been over exploited in order to maintain rapid economic and social development. According to statistics, in 2010, the total water supply in the water receiving region was 53.6 billion $\mathrm{m}^{3}$, of which 24.3 billion $\mathrm{m}^{3}$ was groundwater, accounting for $45 \%$ of the total water supply. For the middle route of the South-North Water Transfer Project, the total amount of groundwater overexploited of Beijing, Tianjin, Hebei, and Henan is 7.18 billion $\mathrm{m}^{3}$, among which Hebei Province accounting for $74 \%$. For the eastern route of the South-North Water Transfer Project, the groundwater was overtaken by 413 million $\mathrm{m}^{3}$ in Shandong Province. The groundwater overexploitation in each water receiving provinces is shown in Figure 1. In addition, the water receiving region with overexploited groundwater problem is $111,900 \mathrm{~km}^{2}$, accounting for $49 \%$ of the water receiving region.

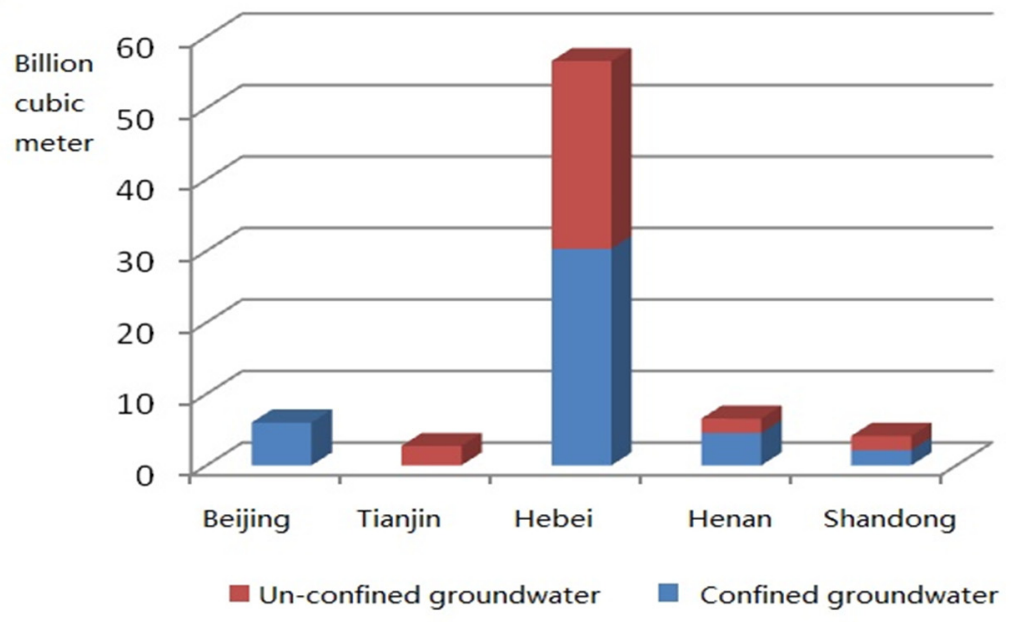

Figure 1 Over-exploited groundwater amount of water receiving provinces

\section{The South-to-North Water Transfer Project provides water source conditions for groundwater overexploitation control}

After more than 10 years of construction, the eastern and middle route of the South-to-North Water Transfer Project have been successfully passed through in 2013 and 2014 respectively. The water supply will increase by 11.2 billion $\mathrm{m}^{3}$ by the South-North Water Transfer Project (see Table 1 for the water volume distribution among the provinces). Through the deployment of various water sources, the over-exploitation of groundwater could be gradually replaced, and the amount of groundwater exploitation could be reduced by 4 billion $\mathrm{m}^{3}$.

Table 1 Water volume distribution among the water receiving provinces of the South-to-North Water Transfer Project

\begin{tabular}{|c|c|c|c|c|c|c|c|}
\hline \multirow{2}{*}{ Water project route } & \multicolumn{6}{|c|}{ Water volume distribution $\left(\times 10^{8} \mathrm{~m}^{3}\right)$} & \multirow{2}{*}{ Total } \\
\hline & Beijing & Tianjin & Hebei & Henan & Jiangsu & Shandong & \\
\hline Eastern route & 1 & 1 & 1 & 1 & 19.25 & 13.53 & 32.78 \\
\hline Middle route & 10.5 & 8.6 & 30.4 & 29.94 & I & 1 & 79.44 \\
\hline Total & 10.5 & 8.6 & 30.4 & 29.94 & 19.25 & 13.53 & 112.22 \\
\hline
\end{tabular}

\section{Effect analysis on groundwater over exploitation control in the water receiving region}

(1) Analysis method of effect analysis on groundwater over exploitation control

In order to master the effect of groundwater over exploitation control in the water-receiving area of the South-to-North Water Diversion Project, the relevant departments have formulated a work plan for evaluating groundwater over exploitation control since 2015. The evaluating method is to calculate the groundwater extraction well number which had been closed since the project passing though of relevant counties and cities in water receiving regions, and based on the water extraction volume by each well, the total decreased groundwater extraction could be obtained. Meanwhile, some other factors could be considered together during the evaluation process, including the water consumption of the South-toNorth Water Transfer Project, the groundwater level, the related institution construction and implementation, etc. At present, three annual evaluations of groundwater over 
exploitation control in the water-receiving area of the South-to-North Water Diversion Project have been carried out.

(2) Water consumption of the South-to-North Water Transfer Project

Water supplied by The South-to-North Water Transfer Project is the main alternative water source for groundwater over exploitation control in urban water receiving regions currently. Since the project passing

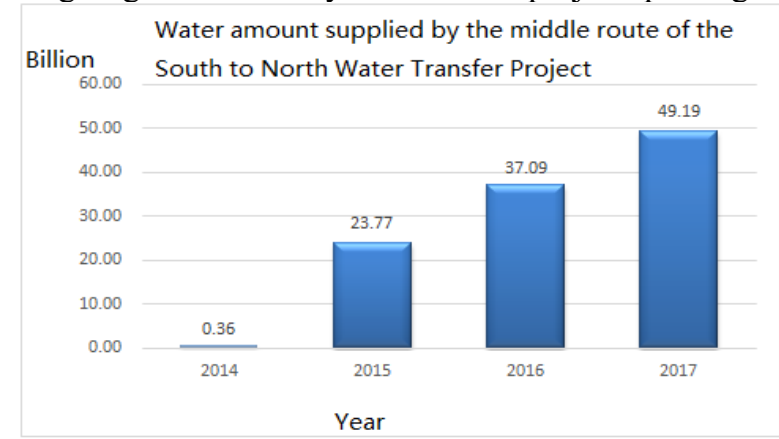

though, the amount of water supplied by the South-North Water Transfer Project has increased year by year. Until august 2018, the water amount supplied by the South-toNorth Water Diversion Project has achieved $18.681 \times 10^{8}$ $\mathrm{m}^{3}$ (including 945 million $\mathrm{m}^{3}$ for ecological water), of which the eastern route project (transferred to Shandong) is 3.067 billion $\mathrm{m}^{3}$ (including 80 million $\mathrm{m}^{3}$ for ecological water), the middle route project is 15.614 billion $\mathrm{m}^{3}$ (including 865 million $\mathrm{m}^{3}$ ecological water).

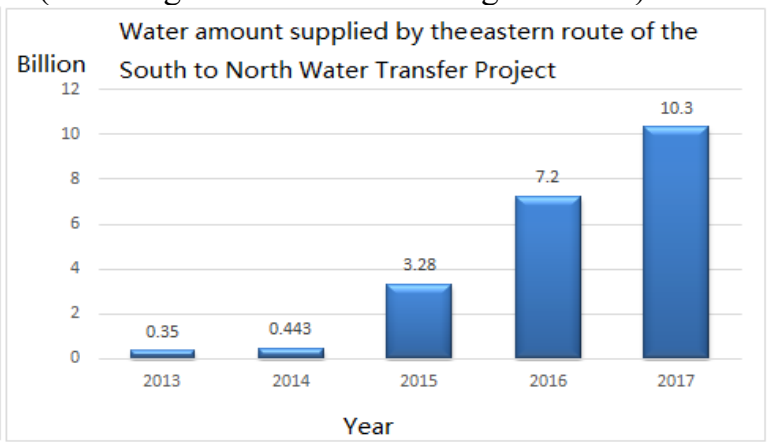

Figure 2 Water amount supplied by the South-to-North Water Transfer Project

(3) Evaluating results for groundwater over exploitation control

The "General Plan for Groundwater Over-exploitation Control in the First Stage of the South-to-North Water Transfer Project"[4] approved by the State Council requires that the water receiving region should make full use of various water source to reduce groundwater exploitation, and the groundwater amount to be reduced is 2.2 billion $\mathrm{m}^{3}$ by 2020 for the urban water receiving regions. Among them, Beijing, Tianjin, Hebei, Henan, Shandong, and Jiangsu should reduced 217 million $\mathrm{m}^{3}, 61$ million $\mathrm{m}^{3}$, 1.456 billion $\mathrm{m}^{3}$, and 237 million $\mathrm{m}^{3}, 229$ million $\mathrm{m}^{3}$, and 10 million $\mathrm{m}^{3}$, respectively.. By the end of 2015 , the waterreceiving area of Jiangsu Province has already pumped 0.35 billion cubic meters of groundwater to complete the target task ahead of schedule.

According to the evaluating results of the past three years, the groundwater exploitation amount has been reduced by 1.523 billion $\mathrm{m}^{3}$ cumulatively in urban waterreceiving area by the end of 2017 with fully utilizing water sources of the South-North Water Transfer Project, accounting for $69.2 \%$ of goal of 2020 . Among them, Beijing reduced 236 million $\mathrm{m}^{3}$, Tianjin 67 million $\mathrm{m}^{3}$, Hebei 639 million $\mathrm{m}^{3}$, Henan 384 million $\mathrm{m}^{3}$, Shandong 162 million $\mathrm{m}^{3}$, and Jiangsu 35 million $\mathrm{m}^{3}$, respectively, accounted for $108.8 \%, 109.8 \%, 43.9 \%, 162.0 \%, 70.6 \%$ and $355 \%$ of the goals of each provinces. On January 1, 2018 , the area with a rising groundwater level (generally less than $2 \mathrm{~m}$ ) accounted for $16 \%$ of total area of water receiving regions, compared with the same period of January 1, 2017. These kind of regions mainly distributed in the plain of south of the Yellow River in Henan Province. There are 50\% regions with a stable groundwater level. Water level still declining area accounted for 34\% (generally less than $2 \mathrm{~m}$, the rate of decline is significantly reduced). Overall, the water level in most parts of the water receiving regions is basically stable or rising. The main reason for still falling groundwater level is that groundwater in some areas is in over-exploitation. In some areas, precipitation is less in 2017, and the effect of groundwater over-exploitation control has a certain lag.

(4) Analysis of groundwater level variation in typical cities

In order to understand the influence of the groundwater over-exploitation control in the South-to-North Water Transfer Project, Shijiazhuang City of Hebei Province was selected as a typical research object, and data from two groundwater monitoring wells located in the groundwater exploitation funnel center were analyzed with a monitoring period from January 2016 until March 2017. The level trend was seen in Figure 3. 


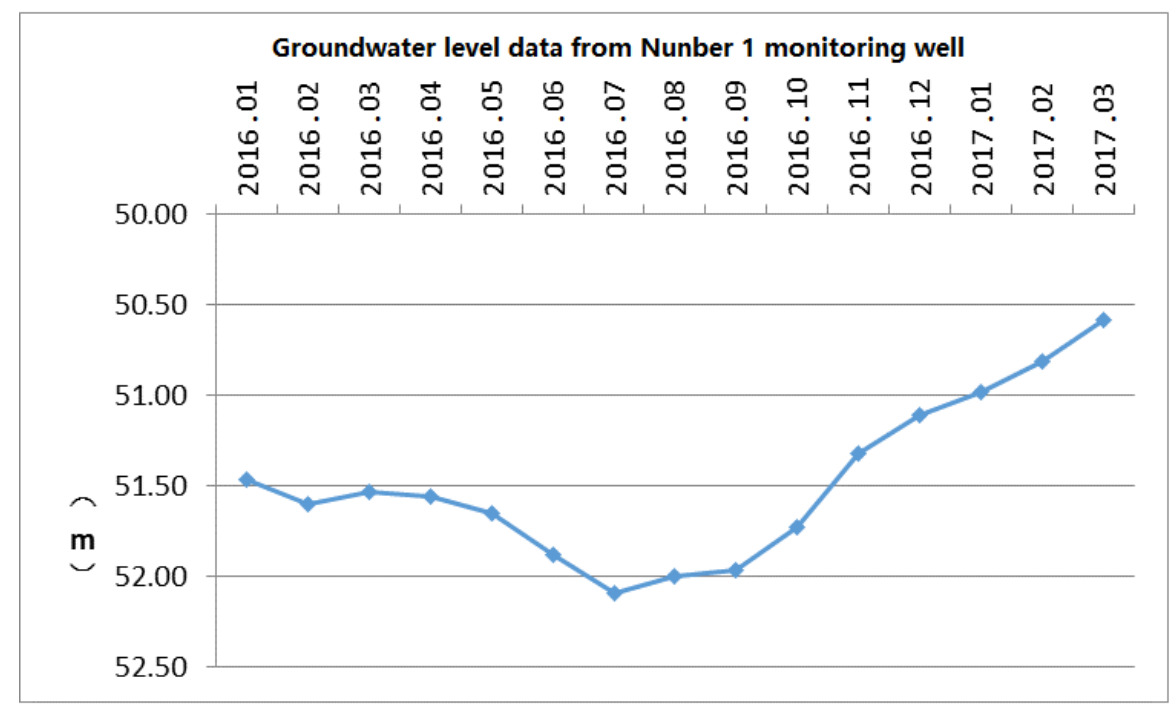

(a)

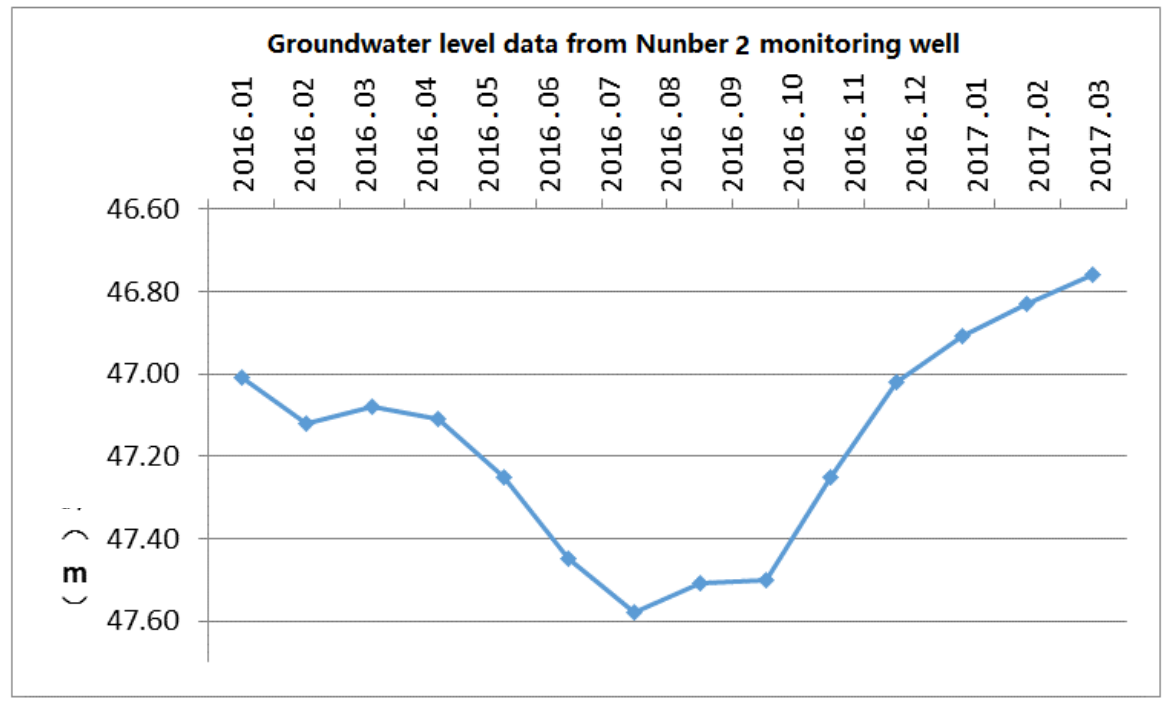

(b)

Figure 3 Groundwater level change trend of monitoring wells in urban Shijiazhuang City

The groundwater level of the two wells was in rising trend overall. The change of groundwater level is mainly affected by two major aspects: the amount of exploitation and the amount of recharge. In 2016, the average precipitation in Shijiazhuang City was $697.3 \mathrm{~mm}$, which was $184.8 \mathrm{~mm}$ more than in 2015 and $154.1 \mathrm{~mm}$ more than the average for many years. Precipitation is the main factor causing changes in groundwater resources. In 2016, the city's groundwater consumption was 1.831 billion $\mathrm{m}^{3}$, which was 178 million $\mathrm{m}^{3}$ less than the groundwater exploitation in 2015. At the same time, in 2015 2016, the water supplied by the South-North Water Transfer Project for Shijiazhuang City was 152 million $\mathrm{m}^{3}$, and these water mainly be used for domestic and industry in urban areas, which contributed a lot to reduce groundwater exploitation. With the increasing precipitation and water supplied by the South-North Water Transfer. The downward trend of groundwater level in urban of Shijiazhuang City has been restrained to a certain extent.

\section{The conclusions}

As a strategic infrastructure to alleviate water shortages in northern China, the South-to-North Water Diversion Project has supplied more than 18 billion $\mathrm{m}^{3}$ of valuable water resources since passing though. Taking this water for alternative water source, the groundwater overexploitation control work was carried out in the water receiving regions and had achieved good results. According to the survey and analysis, 1.523 billion $\mathrm{m} 3 \mathrm{had}$ been reduced for groundwater exploitation at the end of 2017, and the groundwater level in Beijing and other places has begun to rise. The South-North Water Transfer Project has played a significant ecological and environmental benefit.

At present, China attaches great importance to the construction of ecological civilization, and the problem of over-exploitation of groundwater in the North China 
region has also received more and more attention. Groundwater over-exploitation control is an important embodiment of the ecological civilization construction in the water receiving regions of the South-North Water Transfer Project. At present, there are still some problems in groundwater over-exploitation control, including: the communication coordination mechanism for groundwater over-exploitation control has not been played effectively, the water plant and water supply pipe network construction still has the "last mile" problem, and the groundwater over-exploitation control work in rural areas needs to be considered. In order to solve these problems and to promote groundwater over-exploitation control work, it is recommended that the people's governments at the water receiving regions further consolidate the responsibility for groundwater over-exploitation control, make the communication and coordination mechanism play fully role; accelerate the construction of water supply pipe network and water plant project, and start groundwater over-exploitation control in rural areas in a timely manner.

\section{References}

1. LIU Chang-ming, HE Xi-wu. Strategy on water resources issues in Century 21 of China [M]. Science Press, Beijing, 1996. (in Chinese)

2. CHEN Zhi-kai. The Issues of Sustainable Utilization of Water Resources in China. Hydrology, 2003,23(1):1-5. (in Chinese)

3. XU Xin-yi. Reasonable allocation of water of the south-to-north water transfer project is the general planning of theoretical basis $[\mathrm{J}]$. China Water Resources, 2001,8:22-24. (in Chinese)

4. Bureau of South - to - North Water transfer of planning, designing and management, ministry of water resources. General Plan for Groundwater Overexploitation Control in the First Stage of the Southto-North Water Transfer Project [R]. 2002. (in Chinese) 